\title{
ON NONLINEAR FRACTIONAL-ORDER BOUNDARY VALUE PROBLEMS WITH NONLOCAL MULTI-POINT CONDITIONS INVOLVING LIOUVILLE-CAPUTO DERIVATIVE
}

\author{
Ravi P. Agarwal, Ahmed Alsaedi, AlaA Alsharif and Bashir Ahmad
}

Abstract. In this paper, we study some new nonlinear boundary value problems of LiouvilleCaputo type fractional differential equations supplemented with nonlocal multi-point conditions involving lower order fractional derivative. We make use of some well known tools of the fixed point theory to establish the existence of solutions for problems at hand. For illustration of the obtained results, several examples are discussed.

Mathematics subject classification (2010): 34A08, 34B15.

Keywords and phrases: Liouville-Caputo derivative, nonlocal, multi-point, existence, fixed point.

\section{REFERENCES}

[1] R. P. Agarwal, D. O’Regan And S. Hristova, Stability of Caputo fractional differential equations by Lyapunov functions, Appl. Math. 60, 6 (2015), 653-676.

[2] R. P. Agarwal, S. K. Ntouyas, B. Ahmad And A. K. Alzahrani, Hadamard-type fractional functional differential equations and inclusions with retarded and advanced arguments, Adv. Difference Equ., (2016), 2016:92.

[3] B. Ahmad, A. Alsaedi And B. S. Alghamdi, Analytic approximation of solutions of the forced Duffing equation with integral boundary conditions, Nonlinear Anal. Real World Appl. 9, 4 (2008), 1727-1740.

[4] B. Ahmad AND R. P. AgARwal, Some new versions of fractional boundary value problems with slit-strips conditions, Bound. Value Probl., (2014), 2014:175, 12 pp.

[5] B. AhMAD AND S. K. NTOUYAS, Nonlocal fractional boundary value problems with slit-strips boundary conditions, Fract. Calc. Appl. Anal. 18, 1 (2015), 261-280.

[6] B. Ahmad, R. P. Agarwal And A. Als Aedi, Fractional differential equations and inclusions with semiperiodic and three-point boundary conditions, Bound. Value Probl., (2016), 2016:28.

[7] B. Ahmad, A. Als Aedi And A. Alsharif, Existence results for fractional-order differential equations with nonlocal multi-point-strip conditions involving Caputo derivative, Adv. Difference Equ., (2015), 2015:348, $11 \mathrm{pp}$.

[8] B. Ahmad And S. K. NTOUYAs, Some fractional-order one-dimensional semi-linear problems under nonlocal integral boundary conditions, Rev. R. Acad. Cienc. Exactas Fis. Nat. Ser. A Math. RACSAM, 110, 1 (2016), 159-172.

[9] Z. B. BAI AND W. SUN, Existence and multiplicity of positive solutions for singular fractional boundary value problems, Comput. Math. Appl. 63, 9 (2012), 1369-1381.

[10] A. Bits ADZE AND A. S AMARSKII, Some elementary generalizations of linear elliptic boundary value problems (Russian) Dokl. Akad. Nauk SSSR, 185, (1969), 739-740.

[11] R. ČIEGIS AND A. BUGAJEV, Numerical approximation of one model of bacterial self-organization, Nonlinear Anal. Model. Control 17, 3 (2012), 253-270.

[12] J. R. GRAEF AND L. KONG, Existence of positive solutions to a higher order singular boundary value problem with fractional q-derivatives, Fract. Calc. Appl. Anal. 16, 3 (2013), 695-708.

[13] A. Granas And J. Dugundu, Fixed Point Theory, Springer-Verlag, New York, 2003. 
[14] J. HENDERSON AND N. Kosmatov, Eigenvalue comparison for fractional boundary value problems with the Caputo derivative, Fract. Calc. Appl. Anal. 17, 3 (2014), 872-880.

[15] A. A. Kilbas, H. M. SRivastava and J. J. Trujillo, Theory and Applications of Fractional Differential Equations, North-Holland Mathematics Studies, 204, Elsevier Science B. V., Amsterdam, 2006.

[16] S. KONJIK, L. OparniCA, D. ZoriCA, Waves in viscoelastic media described by a linear fractional model, Integral Transforms Spec. Funct. 22, 4-5 (2011), 283-291.

[17] X. LiU, Z. LIU AND X. FU, Relaxation in nonconvex optimal control problems described by fractional differential equations, J. Math. Anal. Appl. 409, 1 (2014), 446-458.

[18] F. Punzo AND G. TerRone, On the Cauchy problem for a general fractional porous medium equation with variable density, Nonlinear Anal. 98, (2014), 27-47.

[19] J. Sabatier, O. P. Agrawal and J. A. T. Machado (Eds), Advances in Fractional Calculus: Theoretical Developments and Applications in Physics and Engineering, Springer, Dordrecht, 2007.

[20] D. R. SMART, Fixed Point Theorems, Cambridge University Press, 1980.

[21] J. R. WANG, Y. ZHOU AND M. MEDVED, Existence and stability of fractional differential equations with Hadamard derivative, Topol. Methods Nonlinear Anal. 41, 1 (2013), 113-133.

[22] J. R. WANG, Y. ZHOU AND M. FECKAN, On the nonlocal Cauchy problem for semilinear fractional order evolution equations, Cent. Eur. J. Math. 12, 6 (2014), 911-922.

[23] X. J. Yang, J. Hristov, H. M. SRivastava And B. Ahmad, Modelling fractal waves on shallow water surfaces via local fractional Korteweg-de Vries equation, Abstr. Appl. Anal., (2014), Art. ID 278672, 10 pp.

[24] G. M. Zaslavsky, Hamiltonian Chaos and Fractional Dynamics, Oxford University Press, Oxford, 2005.

[25] C. ZHAI AND L. XU, Properties of positive solutions to a class of four-point boundary value problem of Caputo fractional differential equations with a parameter, Commun. Nonlinear Sci. Numer. Simul. 19, 8 (2014), 2820-2827.

[26] L. Zhang, G. Wang, B. Ahmad and R. P. Agarwal, Nonlinear fractional integro-differential equations on unbounded domains in a Banach space, J. Comput. Appl. Math. 249, (2013), 51-56.

[27] L. Zhang, B. Ahmad AND G. WANG, Successive iterations for positive extremal solutions of nonlinear fractional differential equations on a half line, Bull. Aust. Math. Soc. 91, 1 (2015), 116-128.

[28] Y. ZHOU, Basic theory of fractional differential equations, World Scientific Publishing Co. Pte. Ltd., Hackensack, NJ, 2014. 